\title{
マルチボディ車両モデルを用いた操舵反カシミュレータのリアリティ向上*
}

\author{
椎葉 太- ${ }^{* 1}$ ，竹生田 利正 ${ }^{* 2}$, 大脇 芳則 ${ }^{* 2}$
}

\section{Enhancement of Reality in Steering Torque Simulator with Multibody Vehicle Model}

\author{
Taichi SHIIBA*1, Toshimasa TAKOUDA and Yoshinori OWAKI \\ ${ }^{* 1}$ Department of Mechanical Engineering, Meiji University \\ 1-1-1 Higashi-Mita, Tama-ku, Kawasaki, 214-8571 JAPAN
}

In this paper, the enhancement of the reality in a steering torque simulator with a multibody vehicle model was discussed. From the perspective of the calculation speed, the augmented formulation and the penalty method were investigated as the formulation of the multibody dynamic analysis, and the step size of the real-time analysis was shortened by embedding matrix libraries to the multibody dynamic analysis. In addition, the friction characteristic of the steering rack of an actual vehicle was experimentally evaluated in order to enhance the reality of the developed simulator. The friction model was identified on the basis of the experimental result and was applied to the multibody dynamic analysis. A slalom test was conducted with the developed simulator and was compared with the experiment of an actual vehicle.

Key Words : Driving Simulator, Maneuverability, Multibody Dynamics, Vehicle Dynamics, Real-Time Analysis

\section{1. 緒言}

自動車を運転するドライバは，視覚情報や操舵反力，摇動感覚などの情報を複合的に判断して操作を行ってい る. 兴のため, ステアリングホイールから伝わる操舵反力は, 人間-車両系を構成する重要な情報の一つであると 考えられる ${ }^{(1)(2)}$. 自動車の開発段階において，この操舵反力の特性をドライビングシミュレータを用いて具現化し， 直感的な評価を行うことで, 開発期間やコストを削減することが提案されている ${ }^{(3)(4)}$. ドライビングシミュレータ では, ドライバのステアリング操作に応じて直ちに操舵反力を算出し, アクチュエータへの指令值として与える 必要があるため, 車両運動および操舵反カのリアルタイム解析が必要となる .

筆者らの研究室では, マルチボディ車両モデルを用いた操舵反カシミュレータを開発している ${ }^{(5)}$. 開発したシ ミュレータの外観を図 1 に示す.このシミュレータでは, マルチボディダイナミクス解析を用いて操舵反力を算 出している．実際の自動車では, 操舵反力の特性はステアリング機構やサスペンションを構成する要素のリンク 配置に加え，機械摩擦の影響を受ける，弚のため，ステアリング機構の機械摩擦の特性を解析に考慮することで， シミュレータのリアリティを向上できると考えられる．しかしながら，一般に機械摩擦は運動方向の変化に応じて 特性が急激に変化するため, 解析を不安定にする要因となる．したがって, 機械摩擦の特性を考慮して安定した 解析を実現するためには，リアルタイム解析の実行周期を向上し，数值積分の時間刻みを小さくする必要がある， 本研究では, 操舵反カシミュレータのリアリティを向上させるために, 実車の摩擦特性を実験的に同定し, マル チボディ車両モデルにおいて考慮することを試みる．併せて，安定したリアルタイム解析を害現するために，又 ルチボディダイナミクス解析の定式化手法について検討し，さらに行列演算ライブラリを応用することで, 操舵 反力解析の実行周期を向上させた . また , 実車走行試験とシミュレータによる試験の結果を比較することで, 操 舵反カシミュレータのリアリティを評価した .

\footnotetext{
* 原稿受付 2013 年 2 月 14 日

${ }^{* 1}$ 正員, 明治大学理工学部機械工学科（干214-8571 神奈川県川崎市多摩区東三田 1-1-1）

*2 明治大学大学院理工学研究科

E-mail: shiiba@isc.meiji.ac.jp
} 


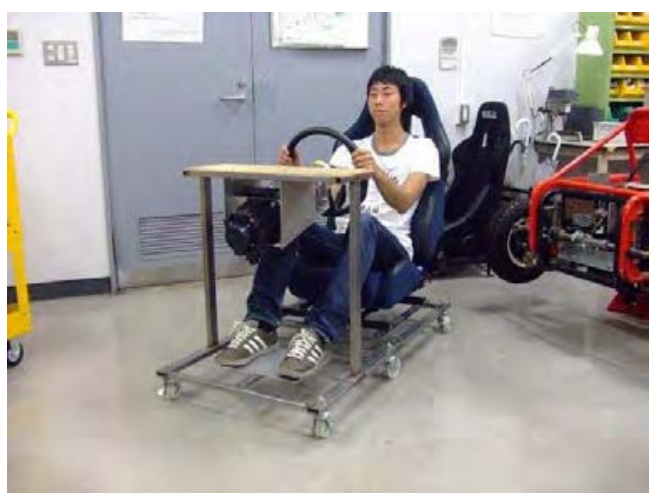

Fig. 1 Steering torque simulator

2. マルチボディダイナミクス解析

$2 \cdot 1$ 本研究で用いた定式化手法

マルチボディダイナミクス解析の定式化手法としては，既にさまざまなアルゴリズムが知られている ${ }^{(6)}$. 本研 究では, 操舵反カシミュレータに適用するマルチボディダイナミクス解析の定式化手法として, 拡大法とペナル ティ法を検討した . マルチボディダイナミクス解析のアルゴリズムとして広く用いられている拡大法 (Augmented Formulation) は, 運動方程式と拘束条件式の双方が含まれる式を取り扱うことになり，式(1)で示される微分代数 方程式 (DAE) に基づいている ${ }^{(7)}$.

$$
\left[\begin{array}{cccc}
\mathbf{M} & \mathbf{0} & \boldsymbol{\Phi}_{\mathbf{r}}^{T} & \mathbf{0} \\
\mathbf{0} & 4 \mathbf{G}^{T} \mathbf{J}^{\prime} \mathbf{G} & \boldsymbol{\Phi}_{\mathbf{p}}^{T} & \boldsymbol{\Phi}_{\mathbf{p}}^{\mathbf{p} T} \\
\boldsymbol{\Phi}_{\mathbf{r}} & \boldsymbol{\Phi}_{\mathbf{p}} & \mathbf{0} & \mathbf{0} \\
\mathbf{0} & \boldsymbol{\Phi}_{\mathbf{p}}^{\mathbf{p}} & \mathbf{0} & \mathbf{0}
\end{array}\right]\left[\begin{array}{c}
\ddot{\mathbf{r}} \\
\ddot{\mathbf{p}} \\
\boldsymbol{\lambda} \\
\boldsymbol{\lambda}^{\mathbf{p}}
\end{array}\right]=\left[\begin{array}{c}
\mathbf{F}^{A} \\
2 \mathbf{G}^{T} \mathbf{n}^{\prime A}+8 \dot{\mathbf{G}}^{T} \mathbf{J}^{\prime} \dot{\mathbf{G}} \mathbf{p} \\
\boldsymbol{\gamma} \\
\boldsymbol{\gamma}^{\mathbf{p}}
\end{array}\right]
$$

ここで， M は質量行列， $\mathbf{J}$ ' は慣性テンソル, $\mathbf{r}$ はボディの重心位置, $\mathbf{p}$ はオイラーパラメータ $, \lambda, \lambda^{\mathbf{p}}$ はラグラン ジュ未定乗数, $\Phi_{\mathrm{r}}, \Phi_{\mathrm{p}}$ は拘束条件式のヤコビ行列， $\gamma, \gamma^{\mathrm{p}}$ は拘束条件式の加速度方程式， $\mathrm{G}$ はオイラーパラメー タにより定義される係数行列, $\mathbf{F}^{A}$ は外力 , $\mathbf{n}^{\prime A}$ はトルクを表している . 拡大法における DAE の係数行列の大きさ は, マルチボディシステムの一般化座標の数 $n c$ に拘束条件式の次数 $n h$ を加えた $(n c+n h) \times(n c+n h)$ のサイズと なる。

ペナルティ法(Penalty Method) は，式(2)のような常微分方程式 (ODE) で表され ${ }^{(8)}$, 拘束条件を違反した際に違 反した量に応じた力をペナルティとして運動方程式に付加したものである .

$$
\left(\mathbf{M}+\Phi_{\mathbf{q}}^{T} \boldsymbol{\alpha} \Phi_{\mathbf{q}}\right) \ddot{\mathbf{q}}+\Phi_{\mathbf{q}}^{T} \boldsymbol{\lambda}=\mathbf{Q}(\mathbf{q}, \dot{\mathbf{q}})-\Phi_{\mathbf{q}}^{T} \boldsymbol{\alpha} \boldsymbol{\gamma}
$$

ここで $\mathbf{q}$ は一般化座標， $\Phi_{\mathbf{q}}$ は拘束条件式のヤコビ行列， $\boldsymbol{\alpha}$ はペナルティ係数， $\mathbf{Q}$ は一般化力である . 違反した拘 束に対する力のゲイン $\boldsymbol{\alpha}$ はペナルティファクタと呼ばれ，一般的に他の行列係数と比較して大きい值が用いられ る. 兴のため, ペナルティ法の ODE は数值的悪条件に陥りやすく，安定して解析を実行するためには数值積分の 時間刻みを小さく設定する必要がある.ペナルティ法における ODE の係数行列の大きさは一般化座標の数 $n c$ の みで表され, $n c \times n c$ となる .

いずれの定式化手法においても，マルチボディダイナミクス解析のフローチャートは図 2 のようになる．また 操舵反力の算出は, 式 (1) および式 (2) に含まれるラグランジュ未定乗数 $\lambda$ を用いて, 式 (3) に示す逆動力学解析 に基づき拘束力 $\mathbf{F}^{\mathbf{c}}$ として算出される.

$$
\mathbf{F}^{\mathbf{c}}=-\boldsymbol{\Phi}_{\mathbf{q}}^{T} \lambda
$$




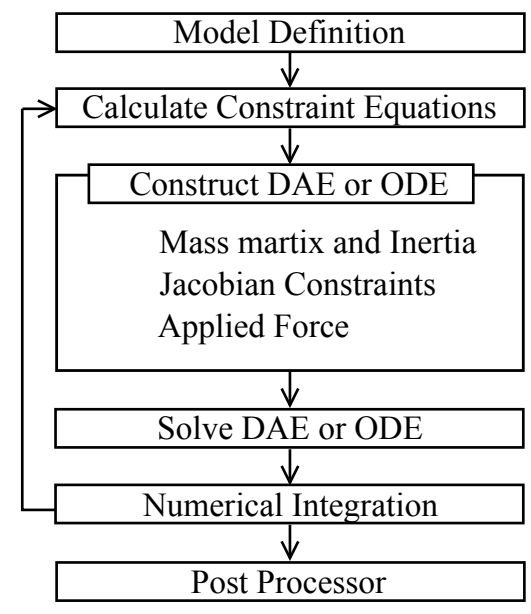

Fig. 2 Flowchart for multibody dynamic analysis

$2 \cdot 2$ 行列演算ライブラリ

マルチボディダイナミクス解析では, 多くの行列演算が必要となるため, 行列演算ライブラリを利用すること で計算時間を短縮することが可能である . 行列演算ライブラリは既に樣々なものが開発されているが，代表的な 系統としては，LAPACK 系行列演算ライブラリとスパース系行列演算ライブラリが挙げられる . LAPACK 系行 列演算ライブラリは，内部でBLAS(Basic Linear Algebra Subprograms) を読み込み，CPUや OS に最適化された コードを用いて高速な演算を実現している．また，スパース系行列演算ライブラリは，行列の要素の多くがゼロ となるスパース行列を対象としたライブラリであり，行列の非ゼロ要素をインデックス化することでメモリサイ ズと計算量を削減し，計算速度を向上している．解析の種類や計算実行環境に応じて，行列演算ライブラリのパ

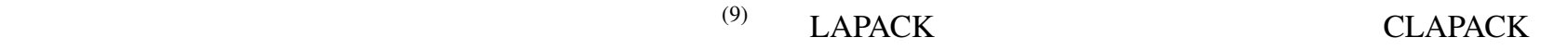
よびCPPLAPACK と，スパース系行列演算ライブラリである KLUおよび SuperLUを用いて，xPC Target 環境に おいて本研究で用いるものと同じ程度の規模の車両モデルを解析した結果, CLAPACK を利用した場合がもっと も計算速度が速いことを確認している .このため, 本研究では行列演算ライブラリとして CLAPACK を用いるこ ととした .

\section{$2 \cdot 3$ 多重振り子モデルを用いた計算時間の評価}

操舵反力シミュレータでは, ドライバの操作に応じた操舵反力を直ちにフィードバックするために, リアルタ イム解析が必要となる．本研究では，リアルタイム解析を実行する環境として，MathWorks 社のxPC Target を使 用している . また , このシステムではアナログ入出カやカウンタ入力などの各種 I/O ボードを利用することが可能 である. 今回の研究では, リアルタイム解析用のPC として，CPU が Intel Core i5 680 (3.6 GHz) のものを用いた . 操舵反カシミュレータにおける評価に先立ち，このリアルタイム解析環境を利用して，図 3 に示す 3 次元の多 重振り子モデルに対し，拡大法とペナルティ法の乥れ光れの定式化手法を用いた際の計算時間を評価した .この 多重振り子モデルでは, 弚れぞれの振り子は剛体として定義されており，剛体間はボールジョイントで拘束されて いる . 振り子の数を $N$ としたとき, 式 (1)および式 (2)の係数行列のサイズは, 拡大法では $11 N+14$ となり， ペ ナルティ法では $7 N+7$ となる .このモデルを用いて，振り子数 $N$ を増加させた際の計算時間の変化を比較した 。 数值積分法として Adams-Bashforth-Moulton 法を使用し，時間刻みを $2 \mathrm{~ms}$ として 1 ステップあたりの計算時間を 計測した . 併せて , 行列演算ライブラリの効果を評価するために , 行列演算ライブラリを使用せずに LU 分解のア ルゴリズムを用いて解析を実行した場合と，行列演算ライブラリを使用した場合について評価を行った .

行列演算ライブラリを使用しない場合と CLAPACK を使用した場合について，振り子の数と 1 ステップの計算 に要した最大の計算時間の関係を図 4 に示す . 図 4 より，行列演算ライブラリを使用することで，拡大法とペナ ルティ法の双方で計算時間を短縮できており，また行列演算ライブラリを使用しない場合はペナルティ法は拡大法 に比べて計算時間が短いが，CLAPACK を使用した場合は关の関係が逆転するという結果が得られた .

この結果について考察するため, 同じマルチボデイ解析プログラムを Windows XP 環境において実行し, 各プ 
ロセスにおける計算時間を評価した .なお, Windows XP はリアルタイム OS ではないため, 計算時間には多少の ばらつきが生じる．このため，ここでは平均の計算時間を用いて評価することにした．振り子の数を $N=6$ とし た際の各プロセスにおける計算時間を，表 1 に示す . 行列演算ライブラリを使用しない場合，拡大法は DAE の求 解のプロセスに多くの計算時間を費やしているが，CLAPACK を用いることでこのプロセスの計算時間が大幅に 短縮されていることが分かる.一方ペナルティ法では，ODE を算出するプロセスの計算時間は拡大法と比較して 長いが, 係数行列のサイズが小さいため, 行列演算ライブラリを使用しない場合でも ODE の求解に要する時間は 短かった .このプロセスも CLAPACK により短縮されたものの，拡大法と比較すると時間短縮の効果が少なかっ たため，逆転現象が生じたことが示されている．

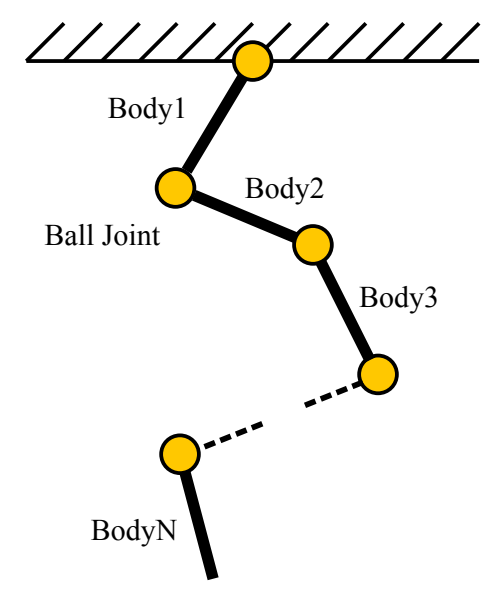

Fig. 3 Multiple pendulum model

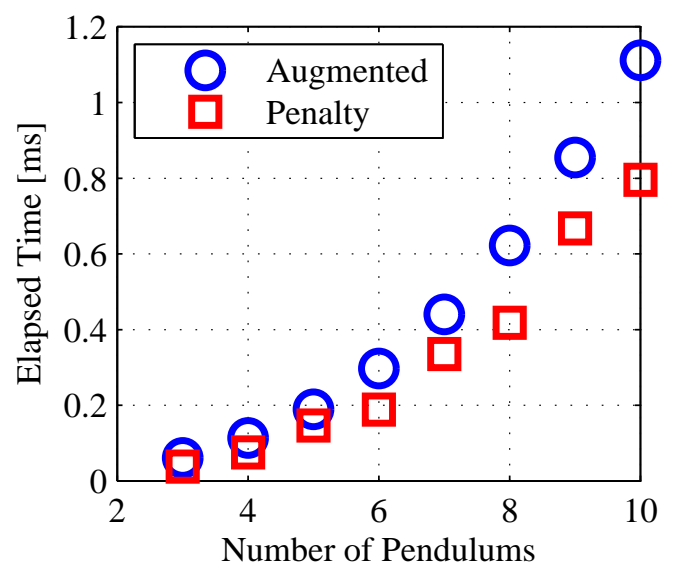

(a) without library

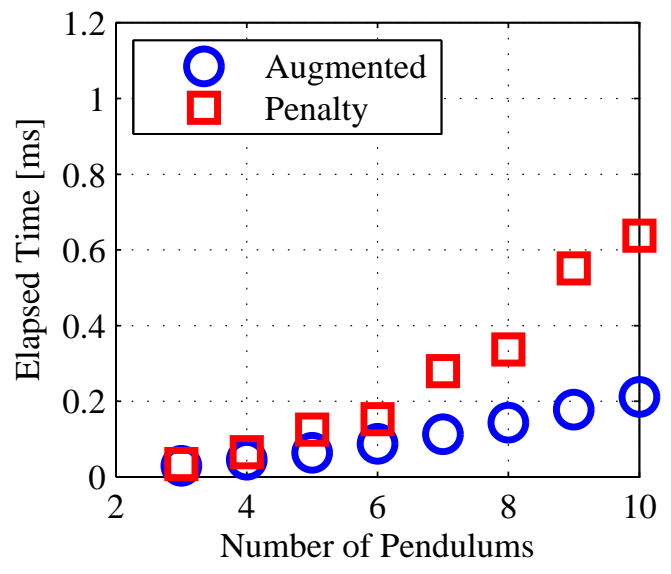

(b) with CLAPACK

Fig. 4 Elapsed time of multibody dynamic analysis

Table 1 Execution Time $(N=6)$

\begin{tabular}{crrrr}
\hline & \multicolumn{2}{c}{ without library } & \multicolumn{2}{c}{ with CLAPACK } \\
Process & Augmented & Penalty & Augmented & Penalty \\
\hline Calculate Contraint Equation & 6.24 & 6.23 & 6.25 & 6.22 \\
Construct DAE or ODE & 10.38 & 60.02 & 10.38 & 57.99 \\
Solve DAE or ODE & 137.91 & 37.27 & 35.51 & 18.37 \\
\hline Total Calculation Time & 321.75 & 195.80 & 98.75 & 152.80 \\
\hline & & & & unit $: \mu \mathrm{s}$
\end{tabular}




\section{3. 操舵反カシミュレータ}

\section{$3 \cdot 1$ 操舵反カシミュレータの構成}

本研究で用いた操舵反カシミュレータの構成を図 5 に示す.ドライバのステアリング操作量は, 図 6 に示す $\mathrm{AC}$ サーボモータに内蔵されたレゾルバにより計測される . 計測された操舵角を入力として , マルチボディ車両モデ ルを用いたリアルタイム解析により，操舵反力を算出する．ここで得られた結果を指令トルクとして AC サーボ モータに与えることで, ドライバは操舵反力を体感することが可能となる .

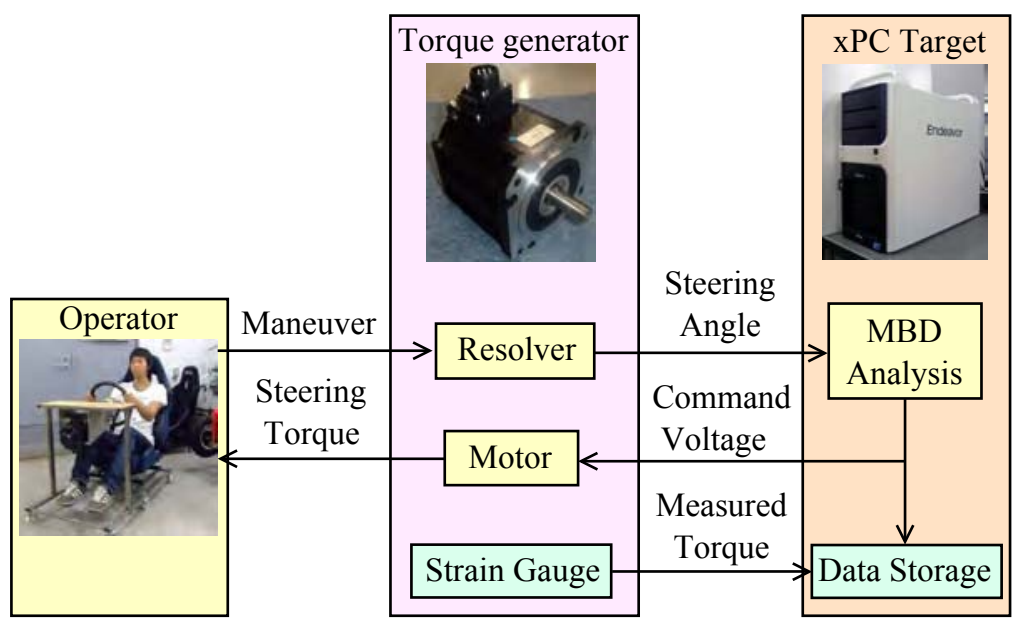

Fig. 5 Steering torque simulator system

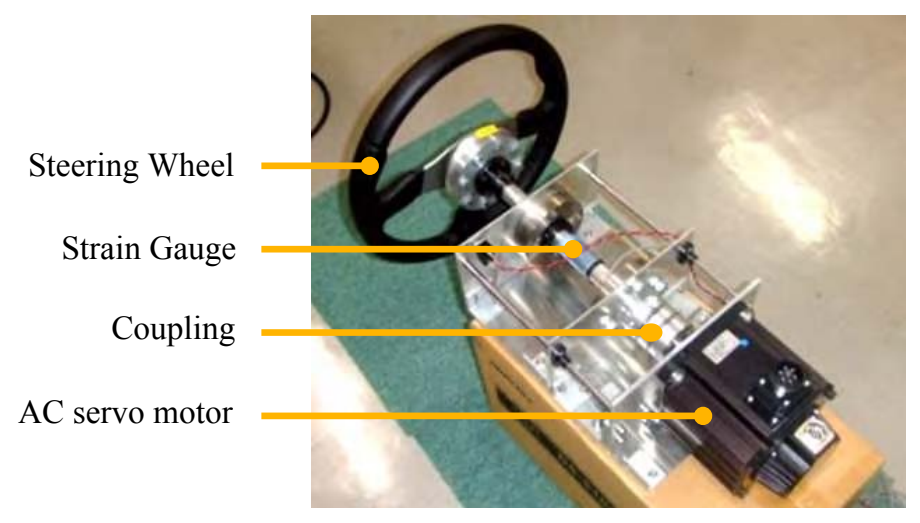

Fig. 6 Torque generator

\section{$3 \cdot 2$ マルチボディ車両モデル}

操舵反カシミュレータでは，図７に示す試験車両を評価対象としている．弚の諸元を表 2 に示す .この車両の情 報に基づき作成されたマルチボディ車両モデルを図 8 に示す.この車両モデルは表 3 に示す 8 個のボディから構 成されている．表 3 には，併せて各ボディの重心位置が示されている．筆者らの過去の研究において，ステアリ ング機構のタイロッドやアッパーアームの質量は車両運動に大きな影響を与えないことか確認されているため ${ }^{(5)}$, アッパーアームとタイロッドを距離拘束として定義することで, 車両モデルのボディ数を削減している．また，サ スペンションのジオメトリを図 9 および図 10 , ならびに表 4 および表 5 に示す . このマルチボディ車両モデルに おいて , ドライバのステアリング操作はステアリングラックの駆動拘束として考慮される .

タイヤモデルについては, 筆者らの研究室において開発したタイヤ試験機 ${ }^{(10)}$ の測定結果に基づくモデルを利用 している．図11に，対象とする車両において利用されているタイヤの測定結果を示す . このグラフは, 3 通りの 接地荷重条件に対する横力およびセルフアライニングトルクの測定結果である. 第 5 章で述べる評価試験の条件 では, 走行中のタイヤに生じるスリップ角は土 $1 \mathrm{deg}$ 前後であり，この範囲では横力およびセルフアライニングト 
ルクともスリップ角にほぼ比例しているとみなせることから , タイヤモデルとしては次式に示されるように接地 荷重依存性を考慮した線形モデルを用いている．

$$
\begin{aligned}
& F_{y}=\left(0.13 \times F_{z}+30\right) \times \alpha-60 \\
& M_{z}=-\left(6.7 \times 10^{-3} \times F_{z}+1.6\right) \times \alpha+1.2
\end{aligned}
$$

ここで， $F_{y}$ はタイヤ横力 $[\mathrm{N}], M_{z}$ はセルフアライニングトルク $[\mathrm{Nm}], \alpha$ はスリップ角 $[\mathrm{deg}], F_{z}$ はタイヤ接地荷 重 $[\mathrm{N}]$ である.なお，スリップ角がより大きい現象を考慮する際には， Magic Formula モデルなど複雑な特性を表 現できるタイヤモデルを利用する必要がある．

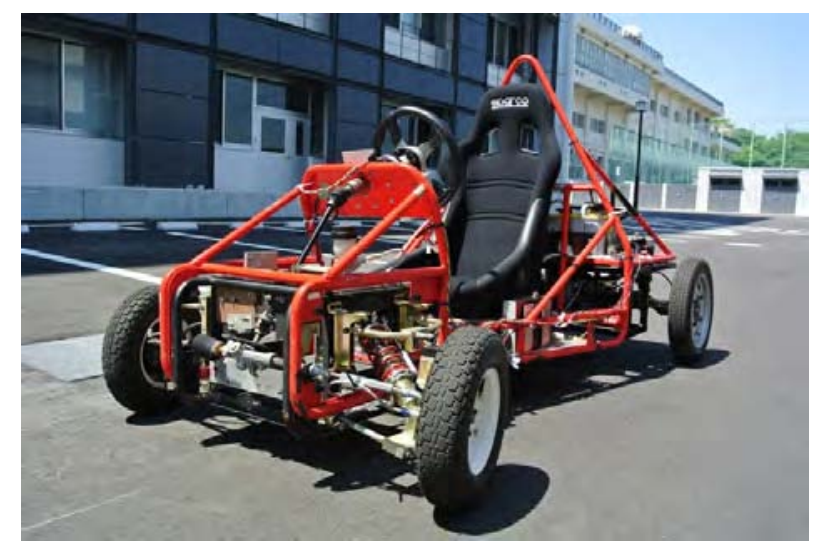

Fig. 7 Experimental vehicle

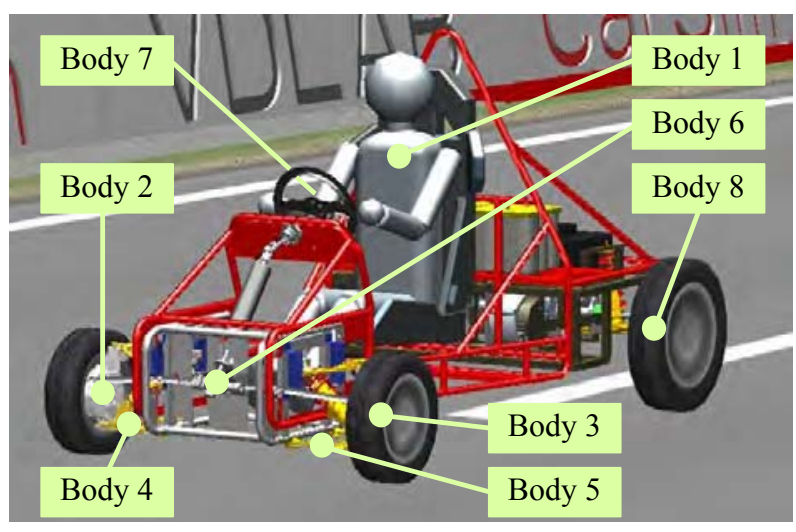

Fig. 8 Multibody vehicle model

Table 2 Experimental Vehicle Specifications.

\begin{tabular}{cc}
\hline Parameter & Value \\
\hline Overall length & $2205 \mathrm{~mm}$ \\
Overall height & $1100 \mathrm{~mm}$ \\
Wheel base & $1865 \mathrm{~mm}$ \\
Tread & $1165 \mathrm{~mm}$ \\
Total mass & $286 \mathrm{~kg}$ \\
Weight distribution & $41.8: 58.2$ \\
Moment of inertia about yaw axis & $123.6 \mathrm{kgm}^{2}$ \\
\hline
\end{tabular}


Table 3 Component Mass and Position of the Center of Gravity.

\begin{tabular}{|c|c|c|c|c|}
\hline \multirow[t]{2}{*}{ Components } & \multirow{2}{*}{$\begin{array}{r}\text { Mass } \\
{[\mathrm{kg}]}\end{array}$} & \multicolumn{3}{|c|}{ The center of the gravity } \\
\hline & & $\mathrm{x} \quad[\mathrm{mm}]$ & y $[\mathrm{mm}]$ & $\mathrm{z}[\mathrm{mm}]$ \\
\hline Main frame & 222.2 & 0.0 & 0.0 & 0.0 \\
\hline Knuckle, front, right & 8.4 & 1349.0 & -536.6 & -183.2 \\
\hline Knuckle, front, left & 8.4 & 1349.0 & 536.6 & -183.2 \\
\hline Lower arm, right & 2.9 & 1322.0 & -406.1 & -284.9 \\
\hline Lower arm, left & 2.9 & 1322.6 & 406.1 & -284.9 \\
\hline Steering rack & 1.4 & 1492.0 & 0.0 & -144.6 \\
\hline Knuckle, rear, right & 19.9 & -473.4 & -525.6 & -134.9 \\
\hline Knuckle, rear, left & 19.9 & -473.4 & 525.6 & -134.9 \\
\hline
\end{tabular}

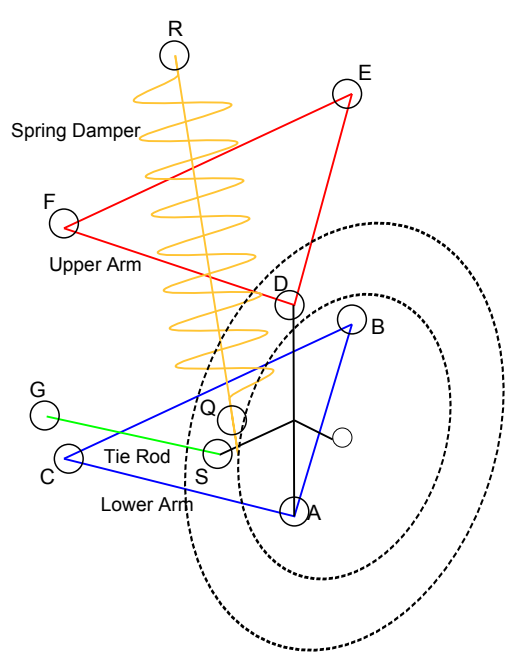

Fig. 9 Front suspension points.

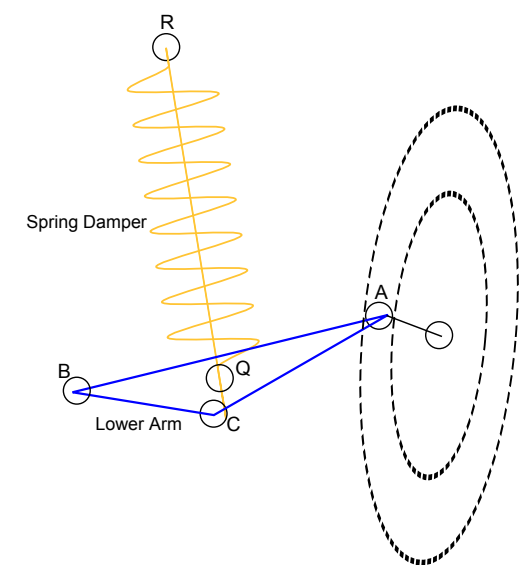

Fig. 10 Rear suspension points.
Table 4 Front suspension points.

\begin{tabular}{cccc}
\hline point & $\mathrm{x}[\mathrm{mm}]$ & $\mathrm{y}[\mathrm{mm}]$ & $\mathrm{z}[\mathrm{mm}]$ \\
\hline A & 1351.0 & 501.7 & -298.7 \\
B & 1151.0 & 249.2 & -280.1 \\
C & 1401.0 & 249.2 & -280.1 \\
D & 1346.0 & 464.2 & -33.5 \\
E & 1151.0 & 272.2 & -66.3 \\
F & 1401.0 & 272.2 & -66.3 \\
G & 1491.0 & 216.0 & -144.6 \\
S & 1448.0 & 501.2 & -149.3 \\
Q & 1334.0 & 419.7 & -227.7 \\
R & 1276.0 & 203.1 & -62.3 \\
\hline & & &
\end{tabular}

Table 5 Rear suspension points.

\begin{tabular}{cccr}
\hline point & $\mathrm{x}[\mathrm{mm}]$ & $\mathrm{y}[\mathrm{mm}]$ & $\mathrm{z}[\mathrm{mm}]$ \\
\hline A & -519.0 & 527.0 & 150.3 \\
B & -277.2 & 261.3 & -130.2 \\
C & -238.0 & 434.0 & -98.2 \\
Q & -390.9 & 411.4 & -110.3 \\
R & -390.8 & 367.5 & 115.5 \\
\hline
\end{tabular}




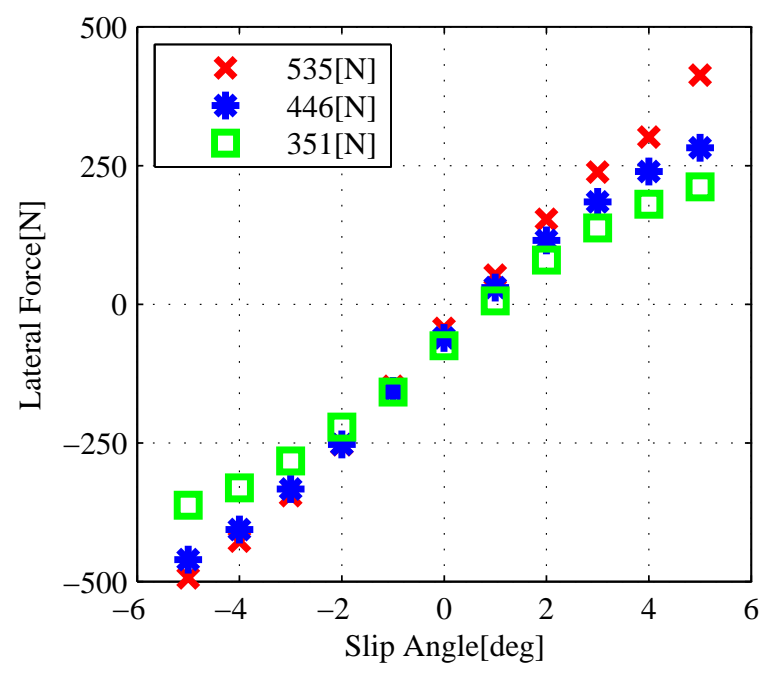

(a) Lateral force

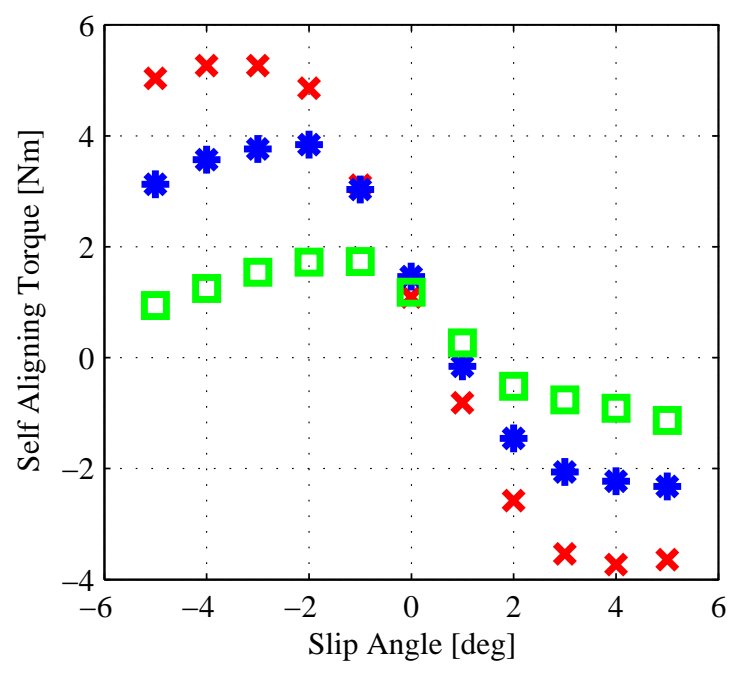

(b) Self aligning torque

Fig. 11 Tire force measured by tire testing machine

\section{$3 \cdot 3$ マルチボディ車両モデルによる計算時間の評価}

前節で述べた車両モデルを用い，xPC Target 環境においてリアルタイム解析を実行し，計算時間を評価した . 多重振り子と同樣に, 拡大法とペナルティ法の光れ光れに対し，行列演算ライブラリを適用しない場合，および CLAPACK を適用した場合について評価を行った . 数值積分法は Adams-Bashforth-Moulton 法を用い，時間刻みは $1 \mathrm{~ms}$ とした . 数值積分の各ステップに要する計算時間を記録し，平均，最大，最小の計算時間を算出した・計算時 間の結果を表 6 に示す. 表 6 より，前節の多重振り子モデルの解析と同樣に，CLAPACK を適用した拡大法の計算 時間が最も短いことを確認できた .この結果を考慮し，以降の操舵反力シミュレータを用いた評価では，CLAPACK を適用した拡大法を用い, リアルタイム解析の実行周期を $0.5 \mathrm{~ms}$ とすることにした .

Table 6 Elapsed time of each formulation

\begin{tabular}{cccc}
\hline Methods & Average & Maximum & Minimum \\
\hline Augmented, without library & 0.8697 & 0.8748 & 0.8663 \\
Augmented, with CLAPACK & 0.3756 & 0.3810 & 0.3689 \\
Penalty, without library & 0.5636 & 0.5666 & 0.5618 \\
Penalty, with CLAPACK & 0.5195 & 0.5232 & 0.5179 \\
\hline & & & Unit: $\mathrm{ms}$
\end{tabular}




\section{4. ステアリング機構の摩擦モデルの同定}

摩擦は全ての機械システムに存在し，部品間の力の伝達に影響を及ぼす ${ }^{(11)}$. ステアリング機構においても，機 械摩擦は操舵反力の特性に大きな影響を与えることが知られている . 乥こで , 筆者らは試験車両のステアリング機 構を用いて，摩擦特性を実験的に評価した . ステアリング機構の摩擦特性は回転方向と角速度に依存する．弚の ため, 図 12 に示すようにトルクセンサをステアリングシャフトに取り付け, ステアリングホイールを一定の角速 度で操舵した際の摩擦トルクを計測した . なお，評価の際にはタイヤとナックルを連結するタイロッドを取り外 し，ステアリングラックにタイロッドの軸力が作用しない状態で計測を行った .ここで得られた計測結果を基に， 式 (6) に示す摩擦卜ルクの数式モデルを同定した . 式 (6) における各係数を表 7 に示す .ここで, 摩擦トルクの単 位は $\mathrm{Nm}$, 角速度の単位は $\mathrm{deg} / \mathrm{s}$ としている . また , 計測された摩擦トルクと同定した摩擦モデルにより算出され る摩擦トルクを図 13 に示す . この摩擦モデルは 5 種類の多項式で表されている.角速度が $10 \leq|\omega| \leq 180 \mathrm{deg} / \mathrm{s} の$ 範囲では, 摩擦トルクは最小二乗法に基づいた 5 次の多項式で表現され，各多項式の接点では接線連続性が確保 されている．今回の計測において，摩擦トルクを計測する際に，| $|\omega| \leq 10 \mathrm{deg} / \mathrm{s}$ の条件で一定角速度を得ることが 出来なかったため, この範囲は直線て繋いだものを使用している.

$$
T_{f}=\left\{\begin{array}{lr}
a_{1} \omega+a_{0} & (\omega \leq-180) \\
b_{5} \omega^{5}+b_{4} \omega^{4}+b_{3} \omega^{3}+b_{2} \omega^{2}+b_{1} \omega+b_{0} & -180<\omega \leq-10) \\
c_{1} \omega & (-10<\omega \leq 10) \\
d_{5} \omega^{5}+d_{4} \omega^{4}+d_{3} \omega^{3}+d_{2} \omega^{2}+d_{1} \omega+d_{0} & (10<\omega \leq 180) \\
e_{1} \omega+e_{0} & (180 \leq \omega)
\end{array}\right.
$$

Table 7 Parameter of friction model

\begin{tabular}{cccc}
\hline$a_{1}$ & $2.88 \times 10^{-4}$ & $a_{0}$ & $-1.75 \times 10^{-1}$ \\
$b_{5}$ & $1.09 \times 10^{-11}$ & $b_{4}$ & $-8.46 \times 10^{-9}$ \\
$b_{2}$ & $-3.04 \times 10^{-4}$ & $b_{3}$ & $2.41 \times 10^{-6}$ \\
$b_{1}$ & $1.57 \times 10^{-2}$ & $b_{0}$ & $-2.54 \times 10^{-2}$ \\
$c_{1}$ & $1.03 \times 10^{-2}$ & & \\
$d_{5}$ & $1.72 \times 10^{-11}$ & $d_{4}$ & $-1.21 \times 10^{-9}$ \\
$d_{3}$ & $3.10 \times 10^{-6}$ & $d_{2}$ & $-3.51 \times 10^{-4}$ \\
$d_{1}$ & $1.64 \times 10^{-2}$ & $d_{0}$ & $2.88 \times 10^{-2}$ \\
$e_{1}$ & $3.05 \times 10^{-4}$ & $e_{0}$ & $1.75 \times 10^{-1}$ \\
\hline & & &
\end{tabular}

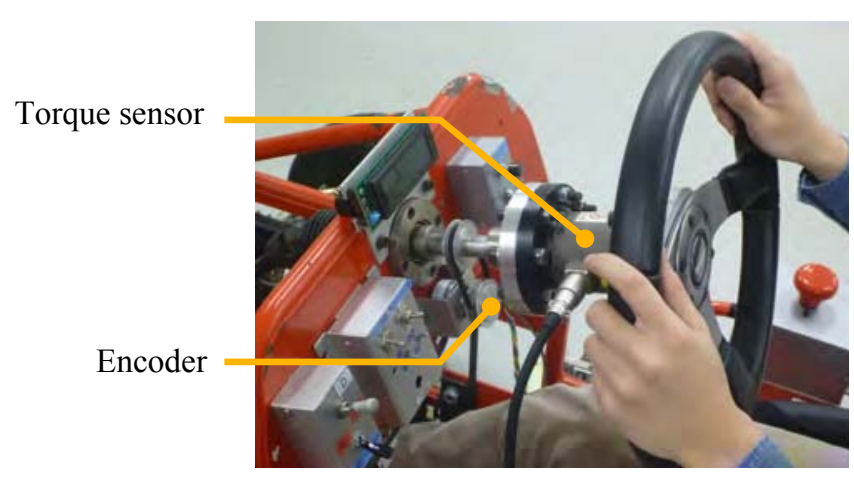

Fig. 12 Environment of measurement 


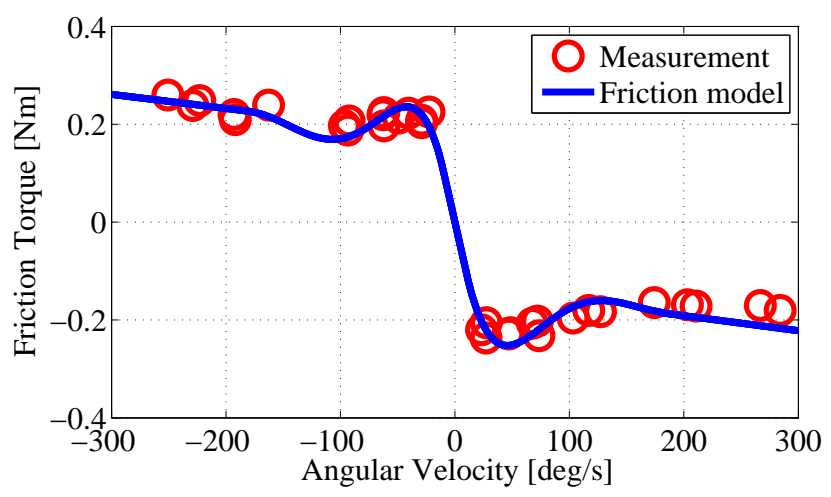

Fig. 13 Measurement and friction model

なお今回の評価では, ステアリング機構全体の摩擦トルクを同定しているが，個々の部品の特性の影響を評価 するためには，弚れ光れの部品について摩擦特性を把握することが望ましい．さらに，タイロッドに作用する負 荷が変化した際には, 同定した摩擦モデルか変化することも考えられる.試験装置の制約により今回はこれらの 評価を行うことができなかったが, 摩擦は非常に複雑な現象であるため, 今後もモデルの精度向上の余地がある と考えている。

\section{5. 実車走行試験と操舵反カシミュレータにおける操舵反力特性の評価}

前章で同定した摩擦モデルを，操舵反カシミュレータにおけるマルチボディダイナミクス解析に適用した .な お，同定した摩擦モデルは，マルチボディダイナミクス解析においては外力項として考慮されるため, 計算時間 にはほぼ影響しないことを確認している . 操舵反力シミュレータにおいて実現される反力特性の妥当性を評価す るため，実車による走行試験と操舵反カシミュレータによる試験の比較を行った . 車速を $15 \mathrm{~km} / \mathrm{h}$ とし，図 14 の 上段に示すような正弦波状のステアリング操舵を入力として与えた際の操舵反力の結果を，時系列データおよび リサージュ波形として図 14 の中段および下段に示す .なお操舵反力シミュレータの結果は, 、ルチボディダイナ ミクス解析により算出された操舵反力の值を示している．また，前章で述べた摩擦モデルの効果を検証するため， 操舵反カシミュレータの結果においては摩擦モデルを考慮しない場合についても結果を示している. 実車走行試 験と操舵反力シミュレータの結果を比較すると，双方の操舵反力特性がよく一致しており，また同定した摩擦モデ ルを操舵反力解析に適用することで, 操舵反力特性の再現性が向上することが示されている . 併せて , 操舵反力 シミュレータにおいて，今回設定した $0.5 \mathrm{~ms}$ という時間刻みで，安定したリアルタイム解析を実行できることが 確認できた .

なお，マルチボディダイナミクス解析の安定性については，普遍的な議論を行うことは容易ではない，解析の 安定性は，対象とするシステムの固有周波数に依存し，併せてシステムに対する入力の特性によっても变化する． 安定性の向上のためには, 陰解法の数值積分法を用いることが有効であるが, 兴の場合は数值減衰の程度につい ても配慮する必要がある.いずれの数值積分法を用いる場合においても，時間刻みを小さく設定することは，解 析の安定性向上を図る上で最初に取るべきアプローチである.また，今回の研究では絶対座標系を用いて車両モ デルを記述した場合についてのみ検討を行っており，相対座標系を利用した再帰的なアルゴリズムについては検 討を行っていない，相対座標を利用した場合は一般化座標の数が減少するため , 行列演算ライブラリの選択につ いても結果が異なることが考えられる．リアルタイム解析の解析効率を向上させるためには，対象とするシステ ムの特性や, 一般化座標の記述方法と定式化手法に配慮したうえで, 解析を実行する計算環境や光の環境に適し た行列演算ライブラリを選択することが重要である． 

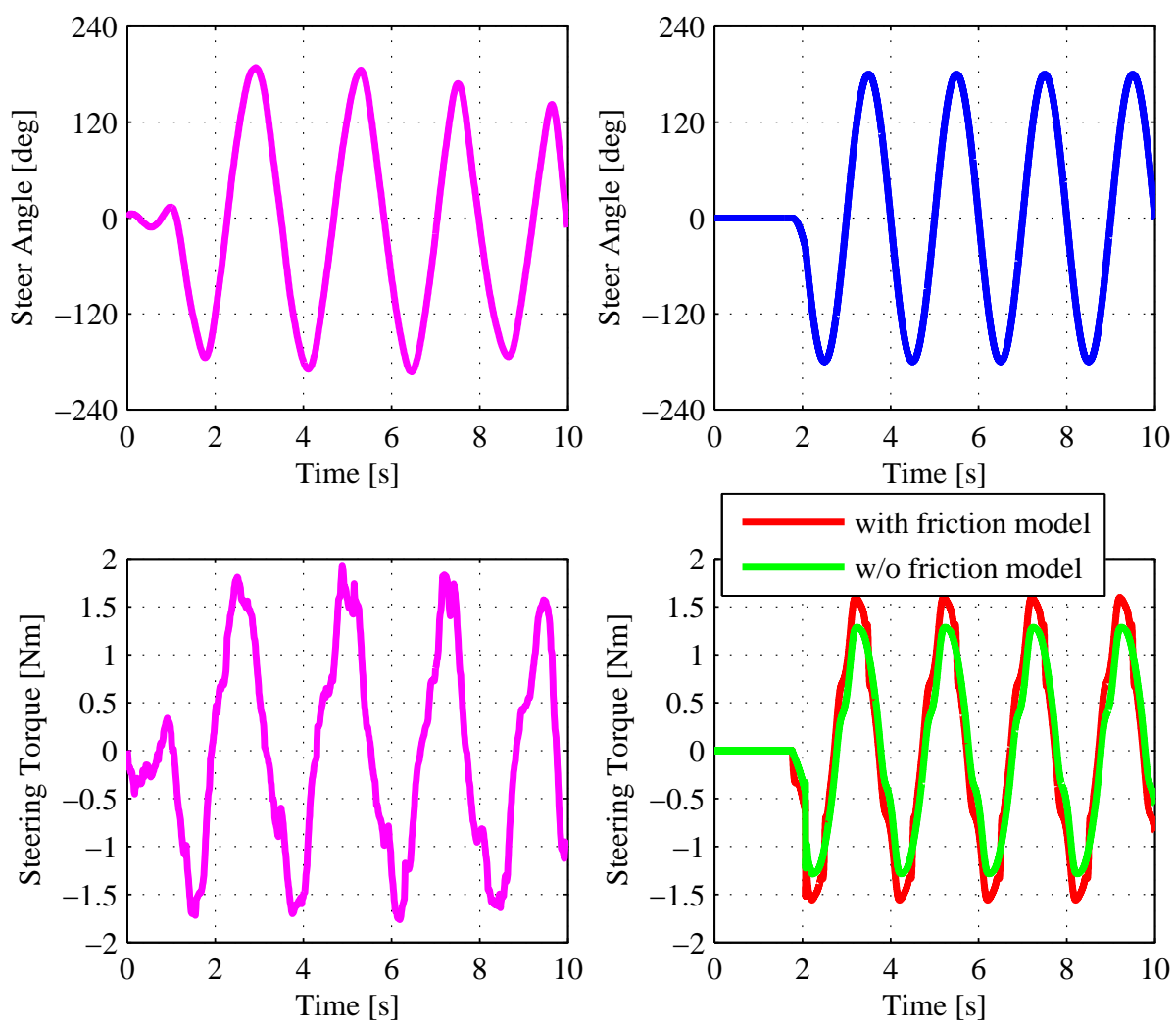

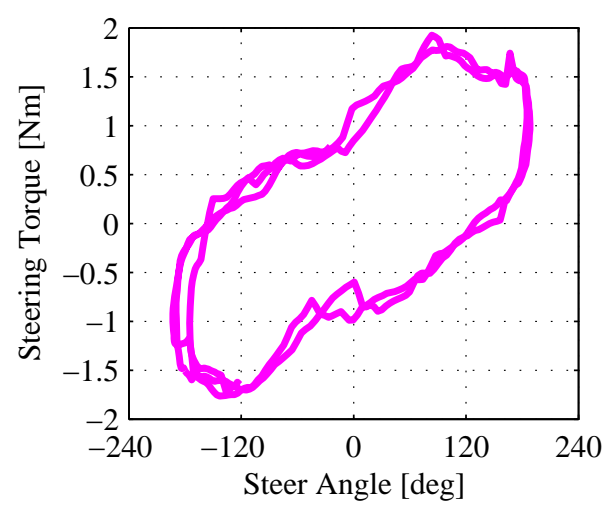

(a) Actual vehicle test

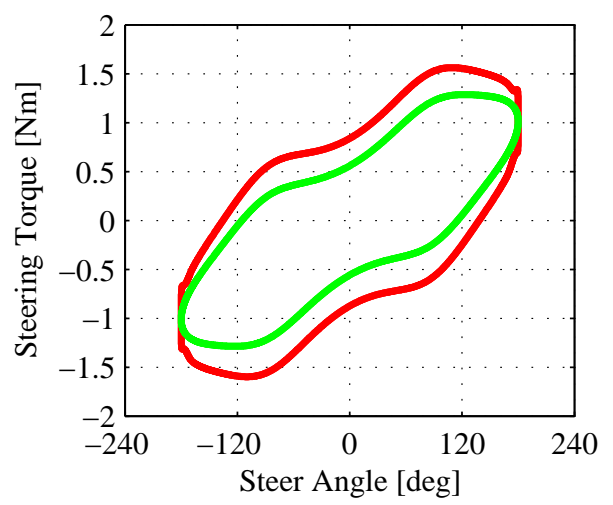

(b) Simulator test

Fig. 14 Slalom test results 


\section{6. 結 言}

本研究では, 操舵反カシミュレータのリアリティを向上させるために, 実車のステアリング機構の摩擦特性を マルチボディ車両モデルにおいて考慮することを試みた．摩擦特性は強い非線形性を持つため，安定したリアル タイム解析を実現するうえで, リアルタイム解析の実行周期を短くすることが重要である. 光こで, 計算時間と いう観点から，マルチボディダイナミクス解析の定式化手法と行列演算ライブラリの適用について検討を行った . 拡大法とペナルティ法の 2 種類の定式化手法を比較したところ，拡大法に行列演算ライブラリのCLAPACK を適 用することにより, 良好なパフォーマンスが得られることを確認した . 併せて , 実車のステアリング機構の摩擦特 性を実験的に同定し，同定した摩擦モデルを操舵反カシミュレータのマルチボディ車両モデルに適用した . 実車 走行試験と操舵反力シミュレータによる試験結果を比較することで, 実車に近い操舵反力特性が再現できたこと を確認した。

\section{文献}

(1) Katzourakis, D., Abbink, D., Happee, R., and Holweg, E., "Steering Force Feedback for Human-Machine-Interface Automotive Experiments", IEEE Transactions on Instrumentation and Measurement, Vol. 60, No. 1 (2011), pp. $32-42$.

（2）瀬川雅也, 藤戸晴彦, 中野史郎, 小竹元基, 永井正夫, “ステアリング HIL シミュレータの開発 (第 2 報ステアリング 操舵性能の定量的評価)”, 日本機械学会第 10 回交通・物流部門大会講演論文集, (2005), pp. 113-116.

(3) Chiew, Y., Abdul Jalil, M., and Hussein, M., "Motion Cues Visualisation of a Motion Base for Driving Simulator", Robotics and Biomimetics, (2008), pp. 1497-1502.

(4) Jung, K., and Jun, C., "A driving simulator as a virtual reality tool”, Robotics and Automation, Vol. 1, (2011), pp. 71-76.

(5) Shiiba, T., and Murata, W., "Experimental Validation of Steering Torque Feedback Simulator through Vehicle Running Test", The Journal of Mechanical Science and Technology, Vol. 23, No. 4 (2008), pp. 954-959.

（6）日本機械学会編, 数值積分法の基礎と応用, (2003), コロナ社.

(7) Haug, E. J., Computer Aided Kinematics and Dynamics of Mechanical System, Allyn and Bacon, (1989), p. 44.

(8) Cuadrado, J., Cardenal, J., and Bayo, E., "Modeling and Solution Methods for Efficient Real-Time Simulation of Multibody Dynamics", Multibody System Dynamics 1, (1997), pp. 259-280.

(9) Shiiba, T., and Naoya, M., "Efficiency evaluation of the real-time multibody analysis with matrix libraries", 5th Asian Conference on Multibody Dynamics, (2010).

(10) 椎葉太一, 河内亮, 森田恵介, “リアルタイム車両運動解析を用いたタイヤ-サスペンション特性評価システムの開 発”, 日本機械学会論文集 C 編, Vol. 76, No. 766 (2010), pp. 1576-1581.

(11) Bazaei, A., and Moallem, M., "Prestiction Friction Modeling and Position Control in an Actuated Rotary Arm", IEEE Transactions on Instrumentation and Measurement, Vol. 59, No. 1 (2010), pp. 131-139.

(12) Wang, Y., Wang, D., and Chai, T., "Extraction and Adaptation of Fuzzy Rules for Friction Modeling and Control Compensation", IEEE Transactions on Fuzzy Systems, Vol. 19, No. 4 (2011), pp. 682-693. 